\title{
CHEMICAL COMPOSITION FROM THE DNIESTER RIVER TRIBUTARIES
}

\author{
Viorica Gladchi ${ }^{\mathrm{a}}$, Gheorghe Duca ${ }^{\mathrm{b}}$, Nelli Goreaceva ${ }^{\mathrm{a}}$, Elena Bunduchi ${ }^{\mathrm{a}}$, Angela Lis ${ }^{\mathrm{a}}$ \\ ${ }^{a}$ Faculty of Chemistry and Chemical Technology, State University of Moldova, 60 A. Mateevici str., Chisinau, \\ the Republic of Moldova \\ ${ }^{b}$ Academy of Sciences of Moldova, Stefan cel Mare 1, Chisinau, the Republic of Moldova \\ *E-mail:vgladchi@yahoo.com; phonenumber: (+37322)577537
}

\begin{abstract}
This article presents the results obtained in the framework of the project $09.832 .08 .06 \mathrm{~A}$ The role of the tributaries on formation of the Dniester river water and the study of the waters quality of sources/fountains in the catchment area of the Dniester river as sources of water supply and for irrigation in the State Program, Scientific Researches and of the management of waters quality.
\end{abstract}

Keywords: tributary, chemical composition, flow rate, mineralization, redox state

\section{Introduction}

This paper presents preliminary results of study on the chemical composition and impact of the right tributaries on the Dniester river waters during 2009-2010 years.

It was determined that waters of the tributaries is characterized by high mineralization $\left(\Sigma_{\mathrm{i}}=892-1039 \mathrm{mg} / \mathrm{dm}^{3}\right)$, with increasing trend in the share of ions $\mathrm{Cl}^{-}, \mathrm{SO}_{4}^{2-},\left(\mathrm{Na}^{+}+\mathrm{K}^{+}\right)$content with increasing of the mineralization.Greater water hardness $\left(\mathrm{D}_{\text {tot }}=8,3-11,9 \mathrm{mmol} / \mathrm{dm}^{3}\right)$ is mainly conditioned by magnesium salts, with exception of the Bic river waters, where calcium and magnesium intake was approximately equal. Stability of the tributaries waters to acidulation is effectively ensured by the carbonate buffer system. The oxygen saturation of rivers waters has varied significantly: with minimum 45,4-69,6\% and maximum 128-168\%.In the Bik river waters, constant has attested oxygen deficit and even his absence with degree of oxidation (D.O.) $=0,0-0,5 \%$. The report of chemical oxygen demandwithmanganese III reagent (COD-Mn) / chemical oxygen demand with dichromatereagent (COD-Cr) denotes that humic substances are approximately $18-24 \%$ of the total organic substances from the tributaries waters.Comparing the indicator values COD$\mathrm{Cr}$, it was established that the largest quantities of organic substances it contains in the waters of the Ichel river(43.5 $\left.\mathrm{mgO} / \mathrm{dm}^{3}\right)$ and Bic river $\left(40.2 \mathrm{mgO} / \mathrm{dm}^{3}\right)$.In the waters of others two tributaries, the quantities are smaller: river Botna - $29.0 \mathrm{mgO} / \mathrm{dm}^{3}$, river Raut - $24.2 \mathrm{mgO} / \mathrm{dm}^{3}$. The biogenic elements were permanently present in high concentrations in all tributaries waters, sometimes exceeding the MAC.Average total iron content in the waters was $135.27-313.7 \mu \mathrm{g} / \mathrm{dm}^{3}$ and the total copper- of $7.16-11.2 \mu \mathrm{g} / \mathrm{dm}^{3}$. The highest level of peroxidase substrates was attested in river Ichel waters $\left(1.53 \mu \mathrm{g} / \mathrm{dm}^{3}\right)$, followed by those of the Bic river $\left(1.30 \mu \mathrm{g} / \mathrm{dm}^{3}\right)$, the Botna river $\left(0.64 \mu \mathrm{g} / \mathrm{dm}^{3}\right)$, the Raut river $(0.11 \mu \mathrm{g} /$ $\left.\mathrm{dm}^{3}\right)$. The values of the indicator $\mathrm{Sk}_{\mathrm{i}} \cdot\left[\mathrm{S}_{\mathrm{i}}\right] \geq 3 \cdot 10^{-5} \mathrm{~s}^{-1}$ denotes that tributaries waters contained the importante quantities of substances that interrupt the chain of the radical self-purification.

It was demosntrate that tributaries waters have a different impact on the main water artery of the country.

For the Republic of Moldova the study of the chemical formation composition processes of the Dniester river waters and their chemical self-purification capacity becomes an actual problem, which is substantiated by the fact that the Dniester River is a main source of surface water, which ensures the needs of urban and rural areas, the agriculture and the industrial sectors.

Currently the chemical composition and the hydrological regime of the Dniester waters suffer undesirable changes, caused by the increased anthropogenic impact. The numerous hydrotechnical constructions, changing of the river riverbed had negative consequences on the natural processes to formation of hydrological, thermic and chemical regime of the Medial and Lower Dniester [1-7].

Among other risk factors of the chemical composition and the self-purification capacity changing of the Dniester river waters in the territory of the Republic of Moldova an important role rests its tributaries.A increased risk in this sense represents the waters of the most important tributaries of the right-bank of the Dniester: Raut, Ichel, Bic and Botna rivers.

The Raut basin comprises the more watercourses with the length comprised between 40-95 km, the main ones being Copaceanca $(50 \mathrm{~km})$, Cubolta $(92 \mathrm{\kappa m})$, Cainar $(95 \mathrm{\kappa m})$, Small Ciuluc $(61 \mathrm{\kappa m})$ and Cula $(65 \mathrm{\kappa m})$. The river tributaries contribute to the increase of the mineralization, total hardness, pollution with biogenic substances and with organic substances of the Raut waters [11-12]. Beside these, at $212 \mathrm{~km}$ from the source, the Raut river accumulates the wastewaters of the municipality Balti.The tributary pours out the waters into Dniester river to 342 miles from its source, near Ustia village, the Dubasari district.

The Ichel river it pours out into the Dniester at $322 \mathrm{~km}$ from the mouth of the river near the village Cosernita, the Criuleni district. The tributary has a length of $101 \mathrm{~km}$ and an accumulation area of $814 \mathrm{~km}^{2}$. The content of the main 
ions in the river water increases from the source to the mouth, so that near of the river mouth waters reach a higher mineralization $\left(900-1100 \mathrm{mg} / \mathrm{dm}^{3}\right)$ and the total excessive hardness $\left(8,6-10,5 \mathrm{mmol} / \mathrm{dm}^{3}\right)$ [11-12].

The Bic river length is $155 \mathrm{~km}$ and the basin of accumulation is $2150 \mathrm{~km}^{2}$. Hydrological and hydrochemical regime of the Bic river is strongly perturbed as a result of the flow rate adjustment after construction of Ghidighici dam and the discharges into river of the untreated wastewater or poorly treated of the Causeni, Straseni and Chisinau.The volume of the Chisinau municipality wastewater exceeding 3-4 times the natural flow rate of the Bic river, what leads, including, to the reduction of the total hardness and waters mineralization on the increase background of the chlorine ions content on the water course, downstream of wastewater treatment plant of the municipality [11-12].

River Botna has a length of $152 \mathrm{~km}$ and an area of accumulation $1540 \mathrm{~km}^{2}$. The flow rate and the chemical composition determined by the natural factors are basically disturbed through total adjusting of the river course. On river is built a cascade of 3 dams with accumulation lakes, near the village Ulmu, Costesti and Rezeni.At a kilometre from the mouth in the Dniester, the river bed is jammed by a dam with gates, which currently does not work and which has a small drainage capacity of the water from the river in the Dniester, however, in periods of the high waters in the Dniester, his waters enters in the riverbed of the Botna river before and after the respectively dam [11-12].

The total area of the river basins of these tributaries is $63.44 \%$ from the accumulation basin of the Dniester waters on the country territory, including, $40 \%$ it is of the Raut river accumulation basin, the Ichel river $-4.24 \%$, the Bic river $-11.2 \%$ and the Botna river- $8 \%$.

In watershed territory of these rivers live about 1.5 million people, activates various industrial and agricultural enterprises. Thus, these rivers are the collectors of the poorly treated or untreated household wastewater and residual waters. The high level of these rivers pollution is confirmed by results of the multiannual researche [8-11].From the ones exhibited the above it follows the need of research the chemical composition of waters of these tributaries with assessment of their impact on the Dniester river water.

To determine the chemical composition of the tributaries waters and its impact on the Dniester river waters, during 2009-2010, water samples were taken from the tributaries as well from the Dniester river, in the capture points located downstream (200-300 $\mathrm{m}$ ) and upstream $(500 \mathrm{~m})$ from the confluence.

The study of the waters chemical composition in the rivers Raut, Ichel, Bic, Botna and Dniester river included the following determinations: $\mathrm{pH}$, temperature, Oxidation-Reduction Potential (ORP), rH, contents of the main ions and mineralization $(\Sigma \mathrm{i})$, the degree of saturation with oxygen (DO), the concentration of dissolved organic substance (COD$\left.\mathrm{Mn}, \mathrm{COD}-\mathrm{Cr}, \mathrm{COB}_{5}\right)$ and biogenic elements $(\mathrm{N}, \mathrm{P})$, the total content of metals $(\mathrm{Cu}$ and $\mathrm{Fe})$, kinetic indicators ([Red], $\left.\left[\mathrm{H}_{2} \mathrm{O}_{2}\right], \mathrm{Sk}_{\mathrm{i}} \cdot\left[\mathrm{S}_{\mathrm{i}}\right],[\mathrm{OH}]\right)$.

For establishing the quantities of chemicals discharged by each tributary in the Dniester river, was calculated the tributaries flow rate at the time of sampling. For this were made measurements related to the morphology of the riverbed at the river mouth and the water flux speed.

Analysis of water samples was carried out using various chemical and physico-chemical analysis methods [1317].

\section{Chemical composition and processes of self-purification of waters rivers Raut, Ikel, Bic and Botna \\ 2.1. The contents of the main ions}

The Dniester tributaries waters of the right-bank at the river mouth, during 2009-2010, can be characterized as being with the increased mineralization and advanced total hardness. The average values of the main ions content have varied insignificantly from $892 \mathrm{mg} / \mathrm{dm}^{3}$ up to $1039 \mathrm{mg} / \mathrm{dm}^{3}$. The variations of the main ions content over the years were insignificant for all rivers, except the Botna river, whose waters had considerable fluctuations of the mineralization (Tab. 1). Raut and Ichel waters are characterized with the hydrochemical index corresponding $\mathrm{C}^{\mathrm{Mg}}{ }_{\mathrm{II}}$ and $\mathrm{C}_{\mathrm{III}}^{\mathrm{Mg}}$. In the Bic river waters of anions, also, hydrogencarbonate ions dominate, and cations $\left(\mathrm{Na}^{+}+\mathrm{K}^{+}\right), \mathrm{Ca}^{2+}, \mathrm{Mg}^{2+}$ were present in very similar quantities [18]. The Botna river waters were hydrogencarbonate and chlorides class, magnesium group and III type of quality.

For the rivers Raut, Ikel and Botna was identified well-defined linear dependence between the hydrogen ions and the total content of main ions. In waters of these tributaries was observed a clear trend of increasing the concentration of ions $\mathrm{Cl}^{-}, \mathrm{SO}_{4}^{2-}$, of the alkali metal ions $\left(\mathrm{Na}^{+}+\mathrm{K}^{+}\right)$when increase the mineralization. For Bic waters not detected any correlation.

The total hardness average of the Raut, Ikel and Botna river waters constituted $11.0-11.9 \mathrm{mmol} / \mathrm{dm}^{3}$ and of the Bic $-8.3 \mathrm{mmol} / \mathrm{dm}^{3}$. The hardness values for this three tributaries are mainly conditioned by the presence of magnesium salts, and in the case of the Bic river, intake of calcium and magnesium salts in total hardness was roughly equal. 
The contents of the main ions $(\Sigma \mathrm{i})$ and the total hardness $\left(\mathrm{H}_{\mathrm{tot}}\right)$ of the Dniester tributaries waters from the right-bank

(to the numerator - average values, to the denominator - the limits of variation)

\begin{tabular}{|c|c|c|c|c|c|c|c|c|}
\hline \multirow{2}{*}{ 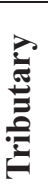 } & \multirow{2}{*}{$\begin{array}{c}\boldsymbol{H}_{\text {tot. }}, \\
\underline{\mathbf{m m o l}^{3}}\end{array}$} & \multicolumn{6}{|c|}{ Ions, $\mathrm{mg} / \mathrm{dm}^{3}$} & \multirow{2}{*}{$\Sigma i, \mathrm{mg} / \mathrm{dm}^{3}$} \\
\hline & & $\mathrm{Ca}^{2+}$ & $\mathrm{Mg}^{2+}$ & $\mathbf{N a}^{+}+\mathbf{K}^{+}$ & $\mathrm{HCO}_{3}^{-}$ & $\mathrm{SO}_{4}^{2-}$ & $\mathrm{Cl}^{-}$ & \\
\hline \multirow{2}{*}{$\underset{\Xi}{\Xi}$} & $10.9 \pm 0.4$ & $67.8 \pm 4.2$ & $91.5 \pm 4.1$ & $76.9 \pm 5.4$ & $\underline{486 \pm 15.9}$ & $171 \pm 4.6$ & $\underline{88.6 \pm 4.6}$ & $982 \pm 25.9$ \\
\hline & 8.1-12 & $52-90$ & $\overline{60.8-102}$ & $55-96$ & $403-546$ & $\overline{149-187}$ & $\overline{63.8-106}$ & $849-1082$ \\
\hline \multirow{2}{*}{$\frac{\widetilde{\Xi}}{ٍ}$} & $\underline{11.6 \pm 0.6}$ & $\underline{78 \pm 4.8}$ & $92.7 \pm 6.5$ & $\underline{33.9 \pm 8.4}$ & $\underline{446 \pm 19.8}$ & $\underline{161 \pm 9.8}$ & $\underline{80.4 \pm 3.4}$ & $\underline{892 \pm 36}$ \\
\hline & 8-13.5 & $58-100$ & 49.9-116 & $10.8-75$ & $342-531$ & $86-182$ & $64-92.6$ & $650-994$ \\
\hline \multirow{2}{*}{ 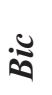 } & $\underline{8.3 \pm 0.61}$ & $\underline{87 \pm 4.16}$ & $\underline{48.3 \pm 5.4}$ & $\underline{118 \pm 11.9}$ & $\underline{426 \pm 9.6}$ & $\underline{147 \pm 10.8}$ & $\underline{107 \pm 4.23}$ & $\underline{933.7 \pm 16}$ \\
\hline & $6.8-10.5$ & $76-102$ & $31-65.7$ & $69.8-147$ & $387-451$ & $120-180$ & $95.7-124$ & $868.8-989$ \\
\hline \multirow{2}{*}{$\underset{5}{5}$} & $\underline{11.9 \pm 1.8}$ & $74.6 \pm 9.5$ & $100 \pm 17.9$ & $101 \pm 26.2$ & $\underline{368 \pm 4.1}$ & $\underline{144 \pm 17}$ & $251 \pm 48.4$ & $\underline{1039 \pm 132}$ \\
\hline & $3.7-17.9$ & $42-122$ & $15.8-158$ & $17.5-238$ & $150-519$ & $57.6-189$ & $42.5-489$ & $356.7-1470$ \\
\hline
\end{tabular}

The mineralization dynamics of the Raut, Ikel and Bic rivers waters during the years was similar and deflected insignificant from the average annual values (Fig. 1). In the waters of the Botna river contents summary of the main ions varied in a wider tuning fork.

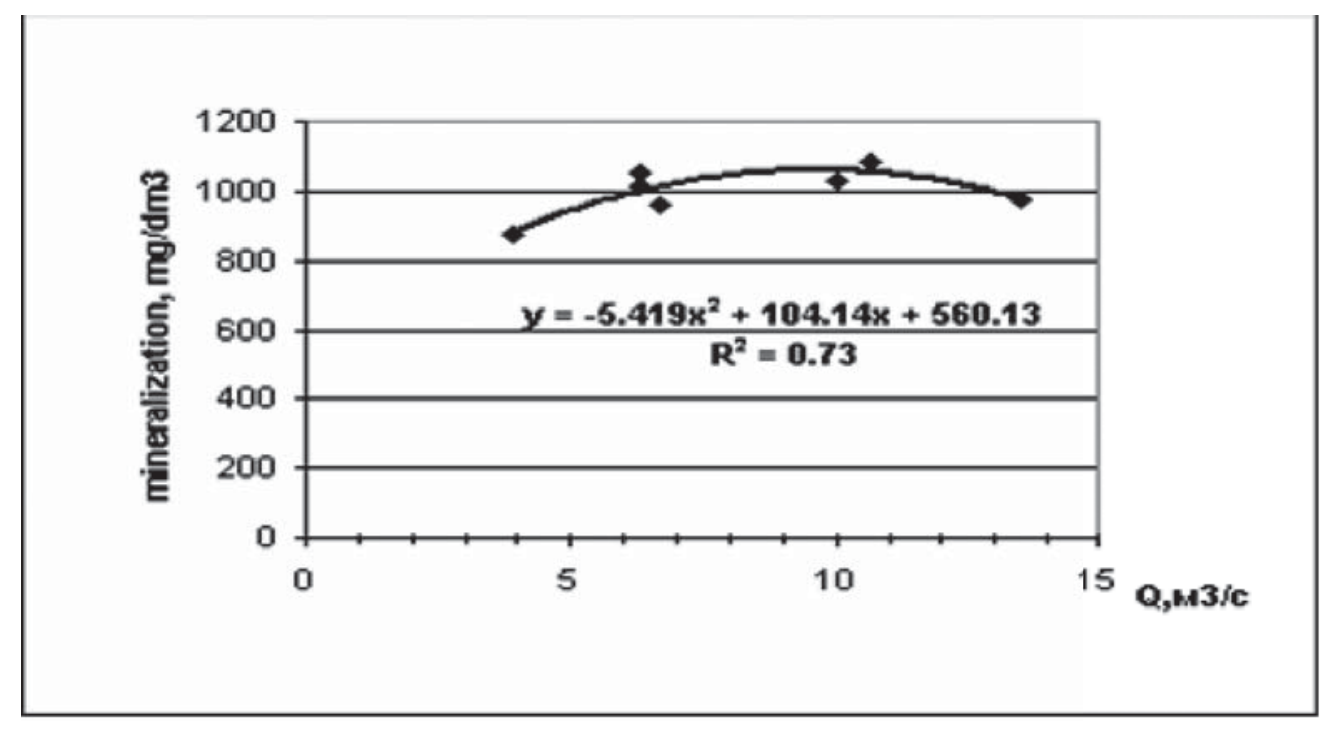

Fig. 1. Dynamics of major ions in the tributaries waters during the years 2009-2010.

For the waters of the Botna river was sudden decrease of the mineralization and total hardness values in cases of the high waters from the Dniester and thereof penetration into the mouth of shedding of the river.

For the Raut river waters was found a good correlation between the mineralization and the water flow (Fig. 2), for the Ichel and Botna rivers this dependence has a low degree of correlation. 


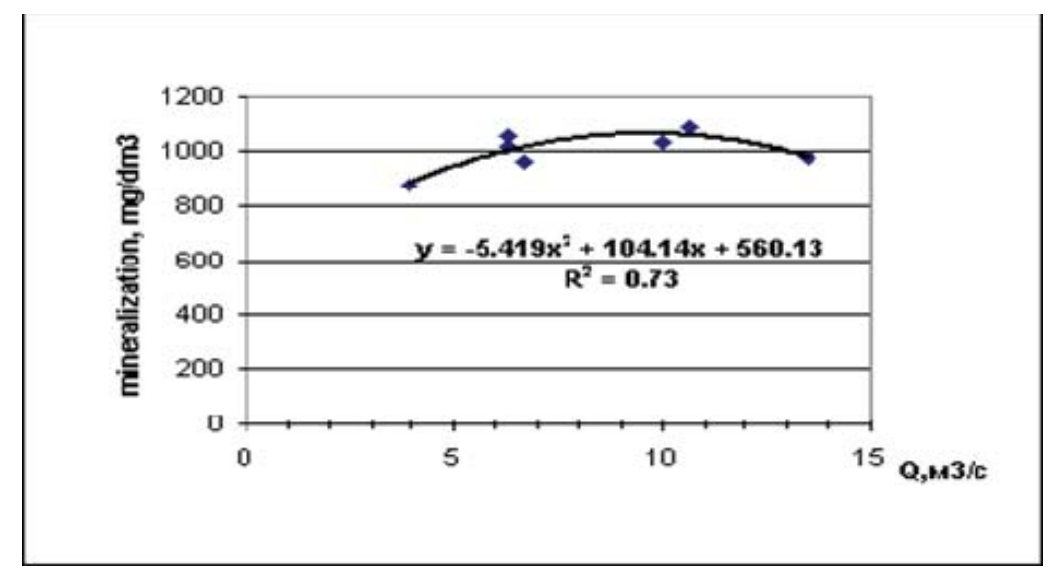

Fig. 2. The correlation between the mineralization and water flow values in the Raut river during the years 2009-2010.

\subsection{The buffering capacity}

Researches related to acid-base balance of the waters and their buffering capacity (after Van Slaic) have not shown the danger of acidification. For all investigated rivers is characteristic relationship stability Alk $>$ Acid, the buffering capacity indicator has not exceeded the alkalinity.However, in water samples from Bic river has found a high content of carbon dioxide, which indicates to the intensive pollution with organic substances and spend with high speed their oxidation processes. The content of $\mathrm{CO}_{2}$ to its mouth in the Dniester river vary between 4.9 and $32.6 \mathrm{mg} / \mathrm{dm}^{3}$, averaging being of $12.13 \mathrm{mg} / \mathrm{dm}^{3}$. In this river values of the waters $\mathrm{pH}$ was always smaller in comparison with other tributaries of the Dniester (Tab.2).

\section{Parameters of acid-base balance and the buffering capacity ( $\beta$ ) of the Dniester tributaries waters from the right-bank}

(to the numerator - the average values, to the denominator - limits variation)

\begin{tabular}{|c|c|c|c|c|c|c|c|c|}
\hline \multirow{2}{*}{ River } & \multirow{2}{*}{ pH } & $\mathrm{HCO}_{3}^{-}$ & Aci & & $\beta$ & \multirow{2}{*}{ pK } & \multirow{2}{*}{$K^{*} 10^{7}$} & \multirow{2}{*}{$\begin{array}{c}\mathrm{CO}_{2} \\
\mathbf{m g} / \mathbf{d m}^{3}\end{array}$} \\
\hline & & \multicolumn{4}{|c|}{ mmol-echiv/dm ${ }^{3}$} & & & \\
\hline Raut & $\frac{8,42}{8,2-8,9}$ & $\frac{8,33}{6,9-10,0}$ & $\frac{0,21}{0,0-0,94}$ & $\frac{8,33}{6,9-10,0}$ & $\frac{0,44}{0,3-0,86}$ & $\frac{6,88}{6,4-7,6}$ & $\frac{1,54}{0,03-3,6}$ & $\frac{3,48}{1,3-6,4}$ \\
\hline Ikel & $\frac{8,25}{7,8-8,4}$ & $\frac{7,52}{5,2-9,1}$ & $\frac{0,23}{0,0-0,33}$ & $\frac{7,52}{5,2-9,1}$ & $0, \frac{0,51}{33-0,8}$ & $\frac{6,76}{6,5-7,2}$ & $\frac{1,92}{0,6-3,4}$ & $\frac{5,12}{1,7-9,9}$ \\
\hline Bic & $\frac{7,83}{7,3-8,1}$ & $\frac{7,18}{6,4-8,3}$ & $\frac{0,61}{0,3-1,14}$ & $\frac{7,18}{6,4-8,3}$ & $0, \frac{0,91}{0-1,31}$ & $\underline{6,56}$ & $\frac{3,24}{1,8-9,1}$ & $\frac{12,13}{4,9-32,6}$ \\
\hline Botna & $\frac{8,44}{8,0-8,8}$ & $\frac{6,15}{2,4-8,5}$ & $\frac{0,16}{0,0-0,62}$ & $\frac{6,15}{2,4-8,5}$ & $0, \frac{0,36}{2-0,48}$ & $\frac{7,18}{6,6-7,8}$ & $0, \frac{0,83}{17-2,4}$ & $\frac{2,18}{0,6-4,2}$ \\
\hline
\end{tabular}

K - acid-base constant

\subsection{The regime ofoxygen}

The content of oxygen in the studied tributaries waters and the degree of saturation of water with oxygen (D.S.) during the investigation period underwent essential variations. The most favourable situation was recorded at the mouth of shedding of the Raut river, where the degree of saturation of the waters with oxygen was maintained favourable, with except situation from 05.07 .2010 , when this parameter has lowered to $61.7 \%$. In the mouths of shedding of the Botna and Ikel rivers, oxygen regime was unstable, ranging from the oxygen-deficient situations (D.S. $45.4-69.6 \%$ ) to the supersaturation (D.S. 128-168\%).At the Bic river mouth of shedding the oxygen regime was unfavourable during the whole period of monitoring, the degree of saturation in 2009 did not exceed more than $69 \%$ and in 2010 vary in the tuning fork $0.0-5.7 \%$.

\subsection{Organic and biogenic substances}

The studied waters in the sections of shedding in Dniester are considerably the polluted with organic and biogenic substances. The average values of organic substances (O.S.), which were determined using indicator COD-Cr, is 24.2 
$\mathrm{mgO} / \mathrm{dm}^{3}$ in Raut, $29.0 \mathrm{mgO} / \mathrm{dm}^{3}$ in Botna, $43.5 \mathrm{mgO} / \mathrm{dm}^{3}$ in Ikel and $40.2 \mathrm{mgO} / \mathrm{dm}^{3}$ in the Bic waters. Maximum values were recorded in Ikel river waters $-126.0 \mathrm{mgO} / \mathrm{dm}^{3}$ (Tab.3).

The contents of organic and biogenic substances in the right tributaries of the Dniester riverwaters.

(to the numerator - the average values, to the denominator - limits variation)

\begin{tabular}{|c|c|c|c|c|c|c|c|c|}
\hline \multirow[t]{2}{*}{ River } & \multirow{2}{*}{$\begin{array}{l}\mathrm{COD}-\mathrm{Cr} \\
\mathrm{mgO} / \mathrm{dm}^{3}\end{array}$} & \multirow{2}{*}{$\begin{array}{l}\text { COD-Mn } \\
\mathbf{m g}_{0} / \mathbf{d m}^{3}\end{array}$} & \multirow{2}{*}{$\begin{array}{c}\mathrm{BOD}_{\mathbf{5}}, \\
\mathrm{mg}_{\mathrm{O} 2} / \mathbf{d m}^{3}\end{array}$} & \multirow[t]{2}{*}{$\underline{\mathrm{BOD}}_{\mathrm{CCO}-\overline{\mathrm{C}} \mathrm{r}}$} & N-NH ${ }_{4}^{+}$ & $\mathrm{N}-\mathrm{NO}_{2}^{-}$ & $\mathrm{N}-\mathrm{NO}_{3}^{-}$ & $\mathrm{PO}_{4}^{3-}$ \\
\hline & & & & & \multicolumn{4}{|c|}{$\mathbf{m g} / \mathbf{d m}^{3}$} \\
\hline \multirow[t]{2}{*}{ Raut } & $\frac{24.2 \pm 5.87}{0.0 .150}$ & $\frac{5.05 \pm 0.66}{2.65}$ & $4.4 \pm 0.59$ & $\underline{0.25 \pm 0.1}$ & $\underline{0.54 \pm 0.24}$ & $\underline{0.042 \pm 0.02}$ & $2.72 \pm 0.73$ & $\underline{2.64 \pm 1.33}$ \\
\hline & $8.0-45.0$ & $2.6-$ & $2.0-7.0$ & $0.07-0.75$ & $0.01-1.91$ & $0.003-0.150$ & $0.50-7.02$ & $0.43-11.4$ \\
\hline \multirow{2}{*}{ Ikel } & $\underline{43.5 \pm 17.8}$ & $\underline{7.9 \pm 1.7}$ & $\underline{7.75 \pm 1.41}$ & $\underline{0.18 \pm 0.04}$ & $\underline{0.91 \pm 0.38}$ & $\underline{0.082 \pm 0.03}$ & $\underline{2.88 \pm 0.71}$ & $\underline{2.39 \pm 1.03}$ \\
\hline & $6.0-126.0$ & $3.8-16.5$ & $4.0-17.0$ & $0.05-0.38$ & $0.03-3.75$ & $0.033-0.26$ & $0.10-7.74$ & $0.08-7.51$ \\
\hline \multirow{2}{*}{ Bic } & $\underline{40.2 \pm 7.9}$ & $\underline{8.4 \pm 1.15}$ & $16.0 \pm 4.9$ & $\underline{0.41 \pm 0.15}$ & $12.54 \pm 3.29$ & $\underline{0.064 \pm 0.040}$ & $2.26 \pm 1.10$ & $\underline{9.15 \pm 2.12}$ \\
\hline & $14.0-56.0$ & & $5.0-34.0$ & $0.10-0.97$ & $2.55-18.2$ & $0.004-0.200$ & $0.10-6.50$ & $1.13-11.8$ \\
\hline \multirow{2}{*}{ Botna } & $\underline{29 \pm 12.9}$ & $\underline{7.02 \pm 0.84}$ & $7.1 \pm 1.39$ & $\underline{0.28 \pm 0.06}$ & $\underline{0.26 \pm 0.09}$ & $\underline{0.071 \pm 0.003}$ & $2.29 \pm 0.81$ & $2.12 \pm 1.3$ \\
\hline & $4.0-45.0$ & $2.56-13.1$ & $3.0-18,0$ & $0.13-0.48$ & $0.0-0.74$ & $0.0-0.170$ & $0.10-8.82$ & $0.0-11.67$ \\
\hline
\end{tabular}

Relationship between the parameters COD-Mnand COD-Cr denotes that the tributaries water contains between $18-24 \%$ humice substances. For all tributaries are characteristics increased values of the parameter $\mathrm{BOD}_{5}$, which characterize biodegradable organic substances [19]. The highest values of the $\mathrm{BOD}_{5}$ parameter in 2009-2010 was registered in the Bic river waters, where its values vary between 5.0 and $34.0 \mathrm{mgO}_{2} / \mathrm{dm}^{3}$. On average, in the waters of the Bic river the share of fresh organic substance formed in the totality of organic substances is $41 \%$. In the Ikel river waters this share is the smallest (18\%) and in Raut and Botna rivers waters, contents of biochemically degradable organic substances are respectively $25 \%$ and $28 \%$.

Analysis of the determinations results for Raut river waters revealed a strong correlation between COD-Cr and COD-Mn parameters and a smaller correlation between parameters COD-Cr and the water flow in the sampling section (Fig. 3).

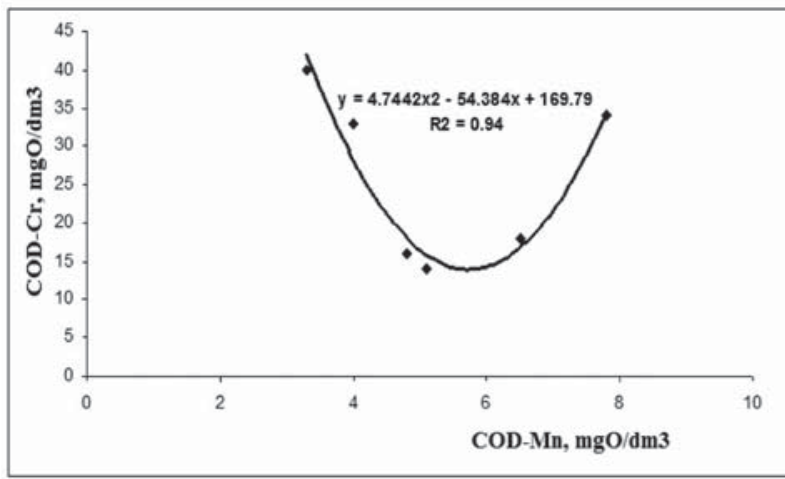

a)

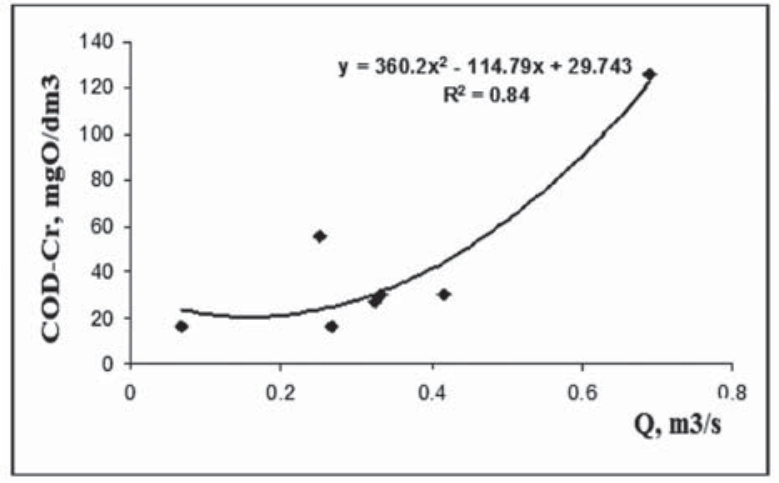

b)

Fig. 3. Correlation between waters quality parameters of Raut river: a) COD-Cr and COD-Mn; b) COD-Cr and debit (Q).

For the Ichel river water have been pointed correlations between parameters COD-Mn, COD-Cr and the water flow (Fig. 4).

The biogenic elements permanently were existent in the waters of all tributaries. In very scarce cases in the water of the Botna river was missing the ammoniacal nitrogen and nitrite ions. The most advanced degree of water pollution with ammoniacal nitrogen was registered in the mouths of the Ikel and Bic rivers shedding, with average values corresponding $0,91 \mathrm{mg} / \mathrm{dm}^{3}$ and 12,54 mg/dm ${ }^{3} \mathrm{~N}-\mathrm{NH}^{4+}$. Minimum content of this nitrogen in the Bic river water exceeded of 1.6 times maximum allowable concentration (MAC)and maximum values exceeded of 11.6 times. 

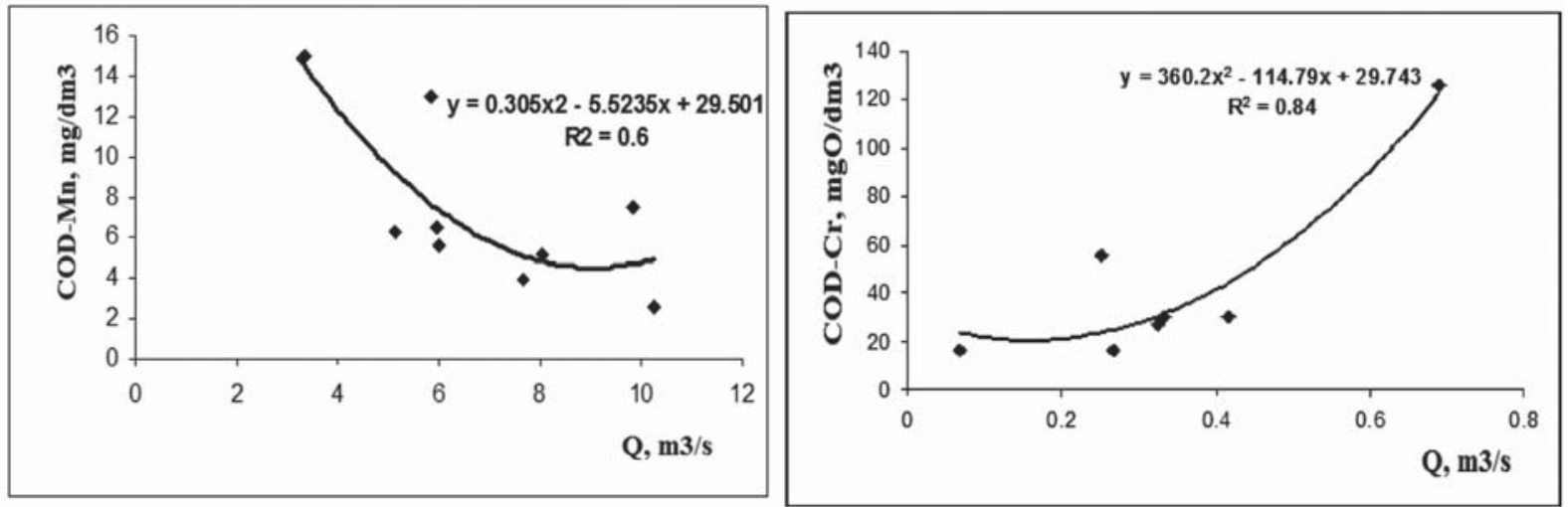

Fig. 4. The correlation between parameters COD-Mn, COD-Cr and waters flow from the Ikel river.

The waters of Dniester tributaries contained a large amount of phosphates. The average values of this parameter was $2.12 \mathrm{mg} / \mathrm{dm}^{3}$ for the Botna river waters, for Ikel river $-2.39 \mathrm{mg} / \mathrm{dm}^{3}$, Raut river $-2.64 \mathrm{mg} / \mathrm{dm}^{3}$ and Bic river -9.15 $\mathrm{mg} / \mathrm{dm}^{3}$. For the Ikel and Raut rivers waters was highlighted a strong correlation between the content of $\mathrm{PO}_{4}^{3-}$ ions and the waters flow $(\mathrm{Q})$.

In the case of the Ichel river, corresponding relationship is: $\mathrm{PO}_{4}^{3-}, \mathrm{mg} / \mathrm{dm}^{3}=12.25 \cdot \mathrm{Q}-1.159 ; \mathrm{r}=0,81$, for the Raut river: $\mathrm{PO}_{4}^{3-}, \mathrm{mg} / \mathrm{dm}^{3}=0,383 \cdot \mathrm{Q}+2,628 ; \mathrm{r}=0,64$.

\subsection{Metalscontent}

The trend of total content of the various forms of copper and iron in the tributaries waters was decreasing from northeast to southwest. In the Raut and Ichel rivers waters the total content of copper and iron is higher in comparison with Bic and Botna rivers waters.

On an average total copper content in the Raut river waters was $11.2 \mu \mathrm{g} / \mathrm{dm}^{3}$, and in the Ichel river - $11.55 \mu \mathrm{g} /$ $\mathrm{dm}^{3}$. For iron in these rivers mean values constituted respectively $313.7 \mu \mathrm{g} / \mathrm{dm}^{3}$ and $282.3 \mu \mathrm{g} / \mathrm{dm}^{3}$ (Fig. 5).

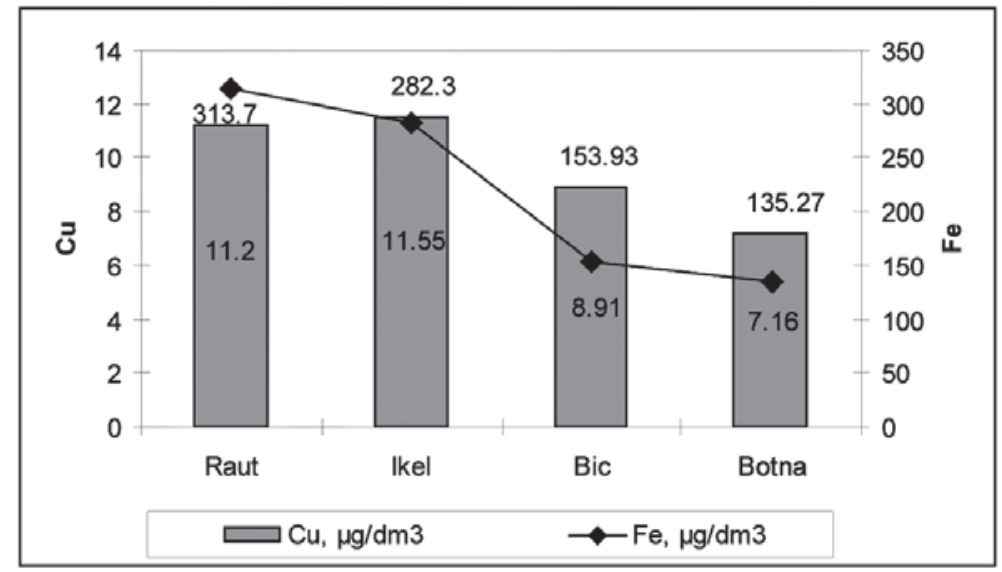

Fig. 5. The average content of copper and iron in the tributaries waters during the 2009-2010 years.

The copper was present in waters in the form of suspensions and colloidal-soluble, their share being roughly the same. Preponderant iron was registered in the form of suspensions (96,6-98,86\%) (tab. 4).

Table 4

The average content of the different forms of copper and iron in the Dniester tributaries waters during the years 2009-2010

(to the numerator - the average values, to the denominator - limits variation)

\begin{tabular}{|c|c|c|c|c|c|c|c|c|}
\hline \multirow{3}{*}{ हे } & \multicolumn{4}{|c|}{ Copper } & \multicolumn{4}{|c|}{ Iron } \\
\hline & \multicolumn{2}{|c|}{$\mathrm{SF}^{*}$} & \multicolumn{2}{|c|}{$\mathrm{CSF}^{* *}$} & \multicolumn{2}{|c|}{$\mathrm{SF}^{*}$} & \multicolumn{2}{|c|}{$\mathrm{CSF}^{* *}$} \\
\hline & $\mu \mathrm{g} / \mathrm{dm}^{3}$ & $\%$ & $\mu \mathrm{g} / \mathrm{dm}^{3}$ & $\%$ & $\mu \mathrm{g} / \mathrm{dm}^{3}$ & $\%$ & $\mu \mathrm{g} / \mathrm{dm}^{3}$ & $\%$ \\
\hline$\stackrel{5}{3}$ & $1.5-12.75$ & $\frac{50.4}{27.3-76.1}$ & $2 \underline{5.0}$ & $\frac{49.6}{23.9-80}$ & $\frac{310.5}{183-482}$ & $\frac{98.86}{98.4-99.6}$ & $2 \frac{3.2}{2.0-4.0}$ & $\frac{1.14}{0.41-1.61}$ \\
\hline
\end{tabular}




\begin{tabular}{|c|c|c|c|c|c|c|c|c|}
\hline হ్ & $\frac{7.15}{1.25-14.2}$ & $\frac{53.6}{20-78.1}$ & $3 . \underline{4.4}$ & $\frac{46.4}{21.9-80}$ & $\frac{279.7}{109.5-469}$ & $\frac{98.76}{97.3-99.6}$ & $\frac{2.6}{2.0-3.0}$ & $\frac{1.24}{0.42-0.67}$ \\
\hline$\because$ & $\frac{4.23}{1.25-6.5}$ & $\frac{44.22}{23.8-61.9}$ & $\frac{4.75}{4.0-6.0}$ & $\frac{52.78}{38.1-76.2}$ & $\frac{150.18}{55.5-167.5}$ & $\frac{96.65}{94.6-98.9}$ & $\frac{3.75}{3.0-6.0}$ & $\frac{3.35}{1.09-5.42}$ \\
\hline בั: & $\frac{3.56}{1.48-6.75}$ & $22.8-77.1$ & $2 . \frac{3.6}{2.0-5.0}$ & $22.9-77.1$ & $\frac{131.9}{76.2-208.7}$ & $93 \frac{96.6}{93.1-98.1}$ & $\frac{4.00}{2.0-6.6}$ & $\frac{3.37}{1.88-6.88}$ \\
\hline
\end{tabular}

* - suspensions form (SF); ** - colloidal - soluble form (CSF).

\subsection{The kinetic parameters}

After kinetic parameters investigated tributaries waters can be characterized as aquatic objects with unfavourable ecological situation, well the biological value of habitation of the waters for hydrobionts was reduced (tab. 5).

The redox state of the river Raut, Ikel and Bic waters more often was reducing, in water samples was missing the hydrogen peroxide and was found substances with the reducing properties (Red). The mean values indicate that the highest content of peroxidase substrates has been attested in the Ikel river waters $\left(1,53 \mu \mathrm{g} / \mathrm{dm}^{3}\right)$, followed by those of the Bic river $\left(1.30-1,53 \mu \mathrm{g} / \mathrm{dm}^{3}\right)$, in the Botna river water the quantity was lower $\left(0.64-1,53 \mu \mathrm{g} / \mathrm{dm}^{3}\right)$ and the lowest quantity has been established in the Raut river water $\left(0.11-1,53 \mu \mathrm{g} / \mathrm{dm}^{3}\right)$.

Table 5

The average kinetic parameters of the Dniester tributaries waters during the years 2009-2010 (to the numerator - the average values, to the denominator - limits variation)

\begin{tabular}{|c|c|c|c|c|c|}
\hline River & $\begin{array}{l}{\left[\mathrm{H}_{2} \mathrm{O}_{2,}\right]} \\
\mu \mathrm{g} / \mathrm{dm}^{3}\end{array}$ & $\begin{array}{l}{[\text { Red], }} \\
\mu g / \mathbf{d m}^{3}\end{array}$ & $\begin{array}{c}\mathrm{OH}_{h v} \cdot 10^{14} \\
\mathrm{~mol} / \mathrm{dm}^{3}\end{array}$ & $\begin{array}{c}\mathrm{OH}_{b i o} \cdot 10^{17} \\
\mathrm{~mol} / \mathrm{dm}^{3}\end{array}$ & $\Sigma k_{i} \cdot\left[S_{i}\right] \cdot 10^{-5}, s^{-1}$ \\
\hline Raut & $\frac{0,0}{0,0-0,0}$ & $0, \frac{0,11}{0-0,39}$ & $\frac{1,94}{0,1-3,8}$ & $\frac{14,98}{1,1-110,0}$ & $\frac{5,01}{2,96-8,97}$ \\
\hline Ikel & $0, \underline{0,0} 0$ & $\frac{1,53}{0-2,42}$ & $\frac{2,15}{0,31-8,8}$ & $\frac{4,54}{1,2-13,8}$ & $\frac{4,38}{3,4-6,82}$ \\
\hline Bic & $0, \underline{0,0}$ & $\frac{1,30}{0,82-1,90}$ & $\frac{1,4}{0,0-3,2}$ & $\frac{6,26}{2,04-19,0}$ & $\frac{3,38}{1,9-4,9}$ \\
\hline Botna & $\frac{1,06}{0,0-8,5}$ & $\frac{0,64}{0,0-2,4}$ & $\frac{1,96}{0,0-5,1}$ & $2, \frac{7,94}{4-23,0}$ & $\frac{4,22}{1,6-9,2}$ \\
\hline
\end{tabular}

Must to be mentioned that, during the period of monitoring, for the Botna river waters, the date of 27.09.2010, was attested superoxide status, what indicatesabout the presence in the water of this tributary of some quantities of the products and semi-products of the technology cycles, well about an aggressively anthropogenic impact. Establishing both the oxidant status, as well and reducing of the indicates on the considerable depreciation of ecological status an aquatic ecosystem.

The inhibition capacity $\left(\sum \mathrm{k}_{\mathrm{i}} \cdot\left[\mathrm{S}_{\mathrm{i}}\right]-5,01 \cdot 10^{5} \mathrm{~s}^{-1}\right)$, which characterizes the effective constant of interaction of the $\mathrm{OH}$ radicals with the substances of reducing nature, demonstrates that the self-purification process with radicals had a low intake in the overall process of the Raut river water self-purification. The average values of inhibition capacity of the waters rivers Ikel $\left(4,3810^{5} \mathrm{~s}^{-1}\right)$ and Botna $\left(4,22 \cdot 10^{5} \mathrm{~s}^{-1}\right)$ shows that, in the monitored period, the contents of substances which interrupt the chain process of the radical self-purification in the waters of both rivers was roughly the same. Though the concentration of these substances in the Bic river waters was lower, however their quantity was sufficient to reduce the speed of the self-purification process with radicals $\left(3,38 \cdot 10^{5} \mathrm{~s}^{-1}\right)$.

For all monitored rivers was found the tendency of redox agents domination, formed as a result of photochemical reactions, in comparison with their training on the biotic path $\left(\mathrm{OH}_{\lambda}>\mathrm{OH}_{\text {bio }}\right)$. This situation denotes that redox conditions of the waters have not been optimal for intense development of microorganisms that remove in the outer environment the products of vital activity with strong reducing and toxicproperties.

\section{The influence of the right tributaries on the chemical composition of the Dniester river}

The results obtained denote a negative influence of the tributaries waters on the chemical composition and chemical self-purification capacity of the Dniester river waters. The most obvious negative impact have manifested the waters of Raut and Bic rivers. In the Dniester waters downstream of the mouths of the shedding of these tributaries, 
are detected the increase of main ions contents, that determines the waters mineralization $\left(\mathrm{Mg}^{2+}, \mathrm{Na}^{+}+\mathrm{K}^{+}, \mathrm{SO}_{4}{ }^{2-}, \mathrm{Cl}^{-}\right)$ and the values of the total hardness of waters, on average with $41 \%$ in the case of the Raut river and $26 \%$ in the case of the Bic river (fig. 6).

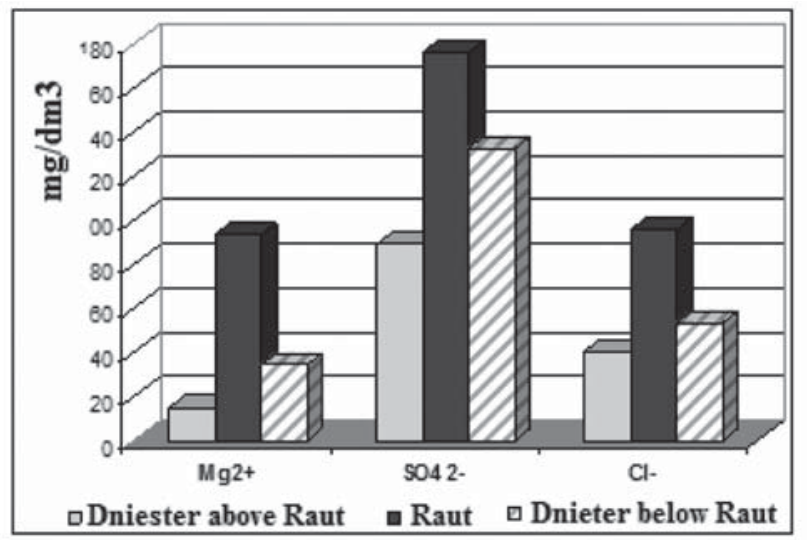

Fig. 6. Influence of the Raut river waters on the main ions content of the Dniester river.

The waters of the Raut and Bic rivers contribute to the increase in pollution of the Dniester river waters with phosphates, compounds of nitrogen, biodegradable organic substances (after the $\mathrm{BOD}_{5}$, fig. 7). In downstream of the shedding of the rivers Raut, Ikel and Botna in the Dniester river waters increase values of the COD-Cr (fig.8-9).

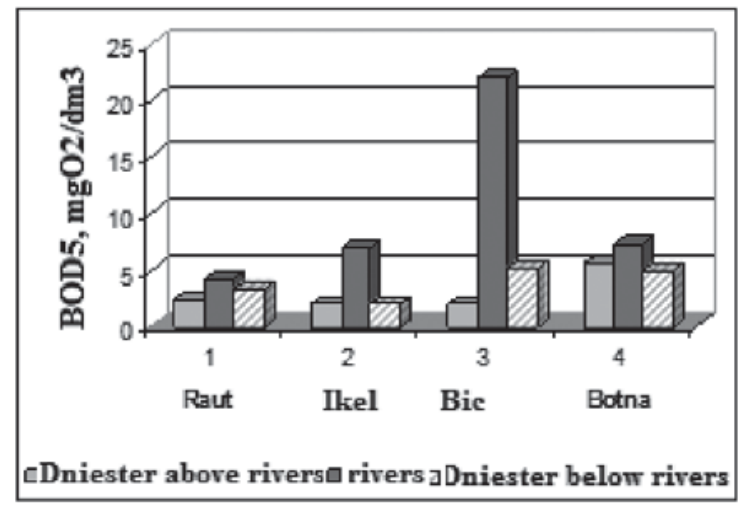

Fig. 7. The impact of tributaries on the content of biodegradable organic substances in the Dniester waters.

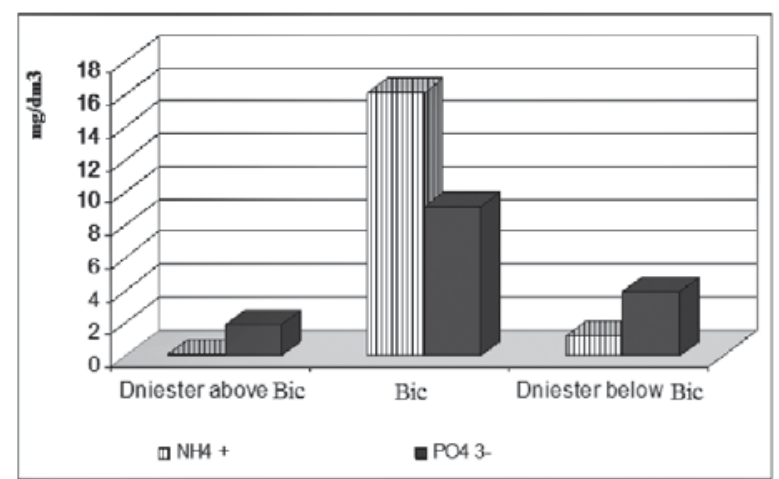

Fig. 8. The influence of Bic river on the contents of biogenic substances in the Dniester river waters.

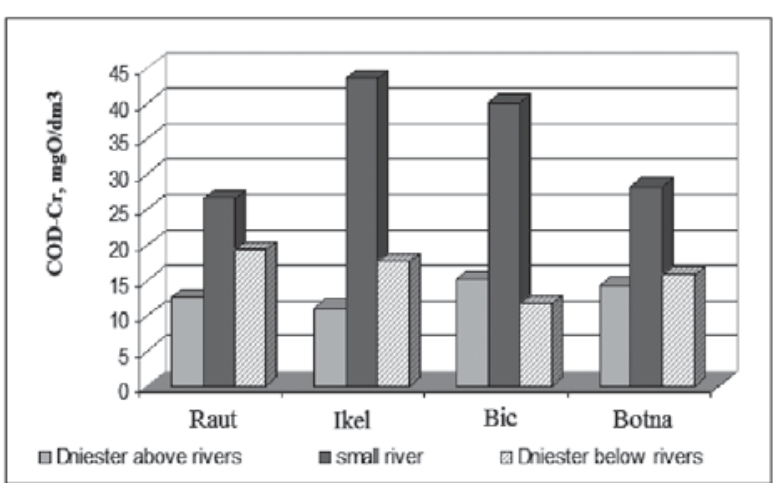

Fig. 9. The impact of tributaries on the content of organic substances in the Dniester waters.

The essential influence of small rivers on chemical composition of the Dniester waters is demonstrated by diurnal flows of some chemical substances which penetrate with the Raut river waters (tab. 6).

The penetration of the polluted waters from tributaries into the Dniester contribute to the reduction of the processes intensity of the river waters chemical self-purification, the dominance of the peroxidase type reductants, the reduction of the $\mathrm{OH}$ radicals content and increasing the inhibition capacity of the waters as against the conduct of the processes with participation of these active particles. 
The average diurnal values of the flow of substances which penetrate into the Dniester with the Raut river waters during the years 2009-2010, in tonnes/day

\begin{tabular}{|c|c|c|c|c|c|c|c|c|}
\hline Year & $\mathbf{Q}, \mathbf{m}^{\mathbf{3}} / \mathbf{s}$ & $\Sigma \mathbf{i}$ & $\mathbf{S O}_{\mathbf{4}}{ }^{2-}$ & $\mathbf{C l}^{-}$ & $\mathbf{C}_{\text {org }}$ & $\mathbf{N}^{-} \mathbf{N O}_{\mathbf{3}}^{-}$ & $\mathbf{N}^{-} \mathbf{N H}_{4}^{+}$ & $\mathbf{P O}_{\mathbf{4}}{ }^{3-}$ \\
\hline $\mathbf{2 0 0 9}$ & 8.41 & 752.4 & 129.1 & 69.59 & 8.66 & 1.65 & 0.464 & 1.065 \\
\hline $\mathbf{2 0 1 0}$ & 10.14 & 848.6 & 144.8 & 68.3 & 5.88 & 1.44 & 0.76 & 4.56 \\
\hline
\end{tabular}

Thus, conducted researches in the period 2009-2010 have demonstrated that the Dniester tributaries may be considered risk factors for the Dniester river waters and the researches in this domain must be continue for analyzing all factors that will contribute to improving the created situation.

\section{Conclusions}

It was been obtained the data about waters chemical composition of the Dniester tributaries ( Raut, Ikel, Bic , Botna) in shedding sections in the Dniester river along the years, as well as was appreciated the chemical composition of the Dniester river in downstream and upstream ofthe tributaries shedding of the mouth and the tributaries contribution in the chemical composition formation of the Dniester river waters.

The data obtained denotes a considerable influence of the Raut river waters on the content of the main ions in the Dniester waters. In shedding downstream of the Raut river, mineral salts content in the Dniester waters increases by $41 \%$.

The Raut and Bic rivers contribute essential to changing the chemical composition of the Dniester river:

- Is observed increaseof the total mineralization and total hardness values of Dniester river waters in downstream of tributaries;

- During the summer period, waters of the Raut and Bic rivers do not correspond the Requirements provided for of Hygienic Regulation. Protection of water basins against pollution (Chisinau, 1997);

- The advanced pollution of the Bic river with biogenic substances $\left(\mathrm{NH}_{3}, \mathrm{NO}_{2}\right.$-and $\left.\mathrm{PO}_{4}^{3-}\right)$ contribute essential to the disruption of aquatic biocoenoses, decreased of the dissolved oxygen content and the disruption of the chemical self-purification processes of the Bic and Dniester rivers waters;

- in summer-autumn colouring is recorded the waters colouring of the Bic river in brown and presence of pronounced smell of the water, what contributes to him "death".

The influence of the Ikel and Botna rivers on the Dniester waters quality is insignificant:

- Ikel has an inessential debit that doesn’t cause important changes in the chemical composition of Dniester river;

- The course of the Botna river is heavily regulated and to the shedding of the tributary in the Dniester is built a dam which basically stops the waters penetration from the Botna into the Dniester.

- Both rivers are characterized by advanced mineralization and increased content of various forms of biogenic elements, which shows a pronounced degree of anthropogenic pollution.

Bank tributary waters are polluted with mineral compounds of biogenic elements - ammonium, nitrite, nitrate, phosphate ions. Maximum concentrations were found at the shedding mouth of the Bic river. Was established trend of increasing concentration of various forms of the biogenic elements in the Dniester waters in downstream of the Bic river shedding.

Researched tributaries have an important influence on the Dniester waters after parameters BOD 5 and COD-Cr.

It was estimated redox state of the Dniester tributaries, and intensity of chemical self-purification processes of the tributaries waters to the confluence with Dniester. After kinetic indicator redox state $\left(\mathrm{H}_{2} \mathrm{O}_{2} / \mathrm{DH}_{2}\right)$, the rivers waters were characterized by unstable redox state (Raut river) or reducing ( Ichel, Bic and Botna rivers). In the tributaries waters almost always were attested substances with reducing properties of peroxidase type, which was oxidized by $\mathrm{H}_{2} \mathrm{O}_{2}$ and thus favoured the establishment of the quasi-reducing state of these waters. Values of redox potential and of $\mathrm{rH}$ denotes that the state of the Dniester waters and those of the Raut, Ikel, and Botna rivers was oxidized, and those from the mouth of the Bic river shedding - reducing. The tributaries waters and those of the Dniester river contained high amounts of peroxidase substances, which has led to the establishment of redox condition unstable of these waters. Oxidation processes mediated of $\mathrm{OH}$ radicals arising effectively in the Dniester waters, but are slowed in those of the tributaries. The dynamics of kinetic parameters demonstrates that the self-purification capacity of the tributaries waters is less than that of the Dniester waters.

5. Acknowledgments: The results have been obtained in the framework of the project $09.832 .08 .06 \mathrm{~A}$ The role of the tributaries on formation of the Dniester river water and the study of the waters quality of sources/fountains in the catchment area of the Dniester river as sources of water supply and for irrigation in the State Program, Scientific Researches and management of waters quality. 


\section{References}

[1]. I.H. Bruma, M.A.Usatii, T.D. Sharapanovskaia, in Environmental and economic problems of the Dniester (Innovative-information center of Odessa "INVATS" Odessa, 1997), p. 28.

[2]. T.D. Sharapanovskaia, in Management of Transboundary Dniester River and the Water Framework Directive of the European Union (ECO-TIRAS, Chisinau, 2008), p. 280.

[3]. E. Zubcova, Ecology 2-3(7), p. 53 (2007).

[4]. E. Zubcova, in Nature Conservancy of Moldova (,Science” Chisinau, 1988), p. 97.

[5]. I.Rusevand others, in Integrated Management of Natural Resources in the Transboundary Dniester River Basin (ECO-TIRAS, Chisinau,2004), p.266.

[6]. V. Gladchi, N. Goreaceva, Gh. Duca, E. Bunduchi, L. Romanciuc, I. Mardari, R. Borodaev, Chem. J. of Moldova, vol.3 (1), p. 70 (2008).

[7]. N. Goreaceva, V. Gladchi, Gh. Duca, E. Bunduchi, R. Borodaev, I. Mardari, L. Romanciuc, in Management of Transboundary Dniester River and the Water Framework Directive of the European Union (ECO-TIRAS, Chisinau, 2008), p.111.

[8]. N. Goreaceva, Gh. Duca, Hydrochemistry of the small rivers of Moldova (Tom. Ed. Centre State. University, of Moldova Chisinau, 2004), 288 p.

[9]. Water Resources of the Republic of Moldova. The surface waters (Science, Chisinau, 2007), $248 \mathrm{p}$

[10]. N. Goreaceva, N.A. Guranda, Environmental problems of Transnistria in Moldova (University, Chisinau, 1992), Causes of the degradation of the small rivers of Moldova, p.112-119.

[11]. N. Goreaceva, in: Self-Purification Processes In Natural Waters (Bulat Art Glob Publishing Company., Chisinau, 1995), p.53-68.

[12]. E. Zubcov, N. Boicenco, D. Schlenk, L. Ungureanu, N. Zubcov, L. Biletski, Z. Bogonin, Bul. The Academy of Sciences of Moldova, 1 (290), p. 135 (2003).

[13]. Guide for chemical analysis land waters (Hydrometeoizdat., Leningrad, 1977), 541p.

[14]. Advanced Water Quality Laboratory Procedures Manual (Hach Company, USA, 1997), Rev. 1, 1140 p.

[15]. A.M. Nicanorov, I.A. Lapin,Reports Academy of Sciences of Moldova, T. 314 (6), p. 1507 (1990).

[16]. P.A. Lozovic, The water resources, T.33, p.15, (2006).

[17]. Technique of definition of the kinetic parameters of surface water quality. Guidance Document. RD 52.18.24.8389 (Hydrometeoizdat, Moscow, 1990), 30 p.

[18]. Gh. Duca, V. Gladchi, N. Goreaceva, E. Bunduchi, R., Borodaev, A. Lis, L.Anghel; O. Şurîghina; L. Romanciuc, Studia Universitatis, ser. natural sciences, 1(31), p. 146 (2010).

[19]. N. Goreaceva, V. Gladchi, Gh. Duca, E. Bunduchi, R. Borodaev, O. Shurigina, Studia Universitatis, ser. natural sciences, 1(31), p. 158 (2010). 